DOI: https://doi.org/10.33330/jurteksi.v6i2.407

Available online at http://jurnal.stmikroyal.ac.id/index.php/jurteksi

\title{
SISTEM INFORMASI INVENTORY P.O.S (POINT OF SALES) BERBASIS WEB PADA COUNTER CELLULAR
}

\author{
Yuggo Afrianto ${ }^{1 *}$, Novita Br Ginting ${ }^{1}$, Suratun ${ }^{2}$, Yashintya Nelawati ${ }^{1}$ \\ ${ }^{1}$ Teknik Informatika, Universitas Ibn Khaldun Bogor \\ ${ }^{2}$ Teknik Elektro, Universitas Ibn Khaldun Bogor \\ email: yuggo@uika-bogor.ac.id
}

\begin{abstract}
Data from the National Socio-Economic Survey of the National Central Bureau of Statistics (Susenas, BPS) 2016 shows that the average amount of national top up the balance spending per month in 2016 reaches $\mathrm{Rp} 22,182$ per capita. It is becoming a business opportunity to top up the balance of retail entrepreneurs. However, in the process of managing the process of input, output and reporting of goods that are done manually (still using paper) are not monitored properly, often there are outgoing or incoming goods whose data is not recorded. This, in the long run, will cause large losses. The purpose of this study is to build applications that function to help provide information that makes it easy to control the process of entry and exit of goods. The system development methodology used is object-oriented system development using the Unified Modeling Language (UML). The results obtained from this research are the design and construction of Inventory Information System POS (Point of Sales) in the form of Context Diagrams and UML Diagrams (Use Case Diagrams, Activity Diagrams, Class Diagrams, and Sequence Diagrams), with the results of black-box testing conducted already in operation properly according to the needs of the retail owner.
\end{abstract}

Keywords: Point of Sales; Retail; UML

\begin{abstract}
Abstrak: Data Survei Sosial Ekonomi Nasional Badan Pusat Statistik (Susenas, BPS) 2016 menunjukkan, jumlah rata-rata pengeluaran pulsa secara nasional per bulan pada 2016 mencapai $\operatorname{Rp} 22.182$ per kapita [1]. Tentu saja hal ini menjadi peluang usaha untuk para pengusaha retail counter. Namun, dalam proses pengelolaannya proses input, output dan pelaporan barang yang dilakukan secara manual (masih menggunakan kertas) tidak termonitoring dengan baik, seringkali terjadi adanya barang keluar ataupun barang masuk yang tidak tercatat datanya. Hal ini dalam jangka panjang akan menimbulkan kerugian yang besar. Tujuan penelitian ini adalah membangun aplikasi yang berfungsi dalam membantu memberikan informasi yang memudahkan dalam pengontrolan proses keluar masuknya barang. Metodologi pengembangan sistem yang digunakan adalah pengembangan sistem berorientasi objek menggunakan Unified Modeling Language $(U M L)$. Hasil yang didapat dari penelitian ini adalah perancangan dan pembangunan Sistem Informasi Inventory P.O.S (Point of Sales) berupa Diagram Konteks dan UML Diagram (Use Case Diagram, Activity Diagram, Class Diagram, dan Sequence Diagram), dengan hasil pengujian black box yang dilakukan telah beroperasi dengan baik sesuai kebutuhan owner retail.
\end{abstract}

Kata kunci: Point of Sales; Retail; UML 
JURTEKSI (Jurnal Teknologi dan Sistem Informasi)

Vol. 6 No. 2, April 2020, hlm. 125 - 134

DOI: https://doi.org/10.33330/jurteksi.v6i2.407

Available online at http://jurnal.stmikroyal.ac.id/index.php/jurteksi

\section{PENDAHULUAN}

Counter DataQu Cellular adalah agen pulsa dan aksesoris yang berada di Bogor, awal mula DataQu Cell merupakan anak dari PT. BestCompindo dengan nama Counter Best Cell, namun saat ini pemiliknya telah beralih tangan dan mengganti namanya menjadi Counter DataQu Cellular.

Selama ini proses input, output dan pelaporan barang hanya secara manual (masih menggunakan kertas), Seringkali terjadi adanya barang keluar ataupun barang masuk yang tidak tercatat datanya. Walaupun counter ini terlihat kecil dan merupakan masalah sederhana namun dalam jangka panjang dapat merugikan dengan jumlah besar, seperti pendahulunya yang mengalami kerugian disebabkan oleh laporan yang dimanipulasikan, adanya kerjasama antara karyawan dengan sales provider dapat merugikan pemilik usaha serta tidak terkontrolnya proses transfer dalam cellular.

P.O.S atau Point of Sales merupakan sistem pencatatan proses jual beli yang terjadi disuatu perusahaan, untuk membantu proses transaksi. POS juga dapat diartikan sebagai check-out counter dan cash register [2]-[4]. Sistem informasi menyediakan kebutuhan pengolahan data transaksi harian yang mendukung fungsi operasi organisasi untuk menyimpan, mengambil, mengubah dan mengolah informasi yang diterima [5]-[9]. Berbagai macam platform aplikasi yang dapat digunakan untuk media informasi, diantaranya website. Halaman website yang dibuat menggunakan bahasa pemrograman dan dan sistem database, seperti HTML, PHP, CSS, MYSQL, untuk menghasilkan kumpulan tampilan yang saling berhubungan sebagai media informasi, komunikasi dan transaksi baik secara statis maupun dinamis [10].

Tujuan penelitian ini adalah membangun aplikasi yang berfungsi dalam membantu memberikan informasi yang memudahkan dalam pengontrolan proses keluar masuknya barang. Metodologi pengembangan sistem yang digunakan dalam membuat aplikasi berbasis web adalah pengembangan sistem berorientasi objek menggunakan Unified Modeling Language (UML).

\section{METODE}

Metode perancangan yang digunakan adalah Extreme Programming. Metode ini merupakan metode yang berorientasi pada kepuasan pengguna. Sehingga sistem bisa dikatakan berhasil jika tingkat kepuasan pengguna terhadap sistem informasi adalah tinggi [11]. Adapun tahapan-tahapan dalam metode Extrame Programming seperti Gambar 1.

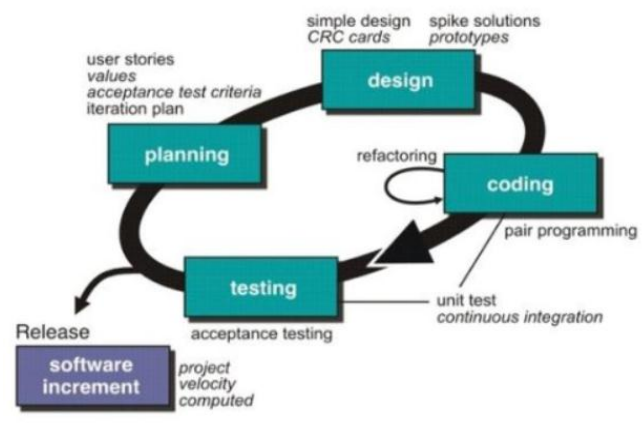

Gambar 1. Tahapan Penelitian Extreme Programming 
DOI: https://doi.org/10.33330/jurteksi.v6i2.407

Available online at http://jurnal.stmikroyal.ac.id/index.php/jurteksi

1) Perencanaan

Dalam proses perencanaan dilakukan pencarian data yang dilakukan di Counter DataQu Cellular Bogor, dengan responden pemilik dan para karyawan. Teknik perencanaan dengan melakukan analisis pengguna, analisis proses bisnis lama dan proses bisnis baru.

2) Perancangan

Dalam tahap perancangan sistem teknik yang digunakan menggunakan UML.

3) Coding atau Implementasi

Dalam tahap coding dilakan penulisan kode program, menggunakan beberapa bahasa pemrogaman. Seperti: HTML, PHP, CSS, Javascript, dan DBMS Mysql.

4) Pengujian

Metode pengujian yang digunakan adalah pengujian black box. Pengujian black box adalah pengujian aspek fundamental sistem tanpa memperhatikan struktur logika internal perangkat lunak [12].

\section{HASIL DAN PEMBAHASAN}

\section{Perencanaan Sistem}

Berdasarkan analisis kebutuhan hasil perancanaan sistem yang didapat adalah sebagai berikut:

\section{Analisis Pengguna}

Berdasarkan hasil observasi dilakukan wawancara dengan pihak pengguna yang dilakukan pada tanggal 15 Desember 2018, pengguna sistem informasi inventory point of sales ini difokuskan pada kebutuhan pegawai dan keinginan pemilik DataQu Cellular. Adapun pengguna yang mengelola data informasi pada sistem informasi inventory P.O.S berbasis website adalah owner dan karyawan DataQu Cellular.

\section{Analisis Proses Bisnis Lama}

Proses bisnis sebelum adanya sistem informasi inventory POS adalah dengan cara mencatat semua barang masuk dan keluar secara manual menggunakan kertas dan selalu melakukan pengecekan pada saat buka dan pada saat ingin tutup (berlangsung setiap hari). Ditunjukkan pada Gambar 2.

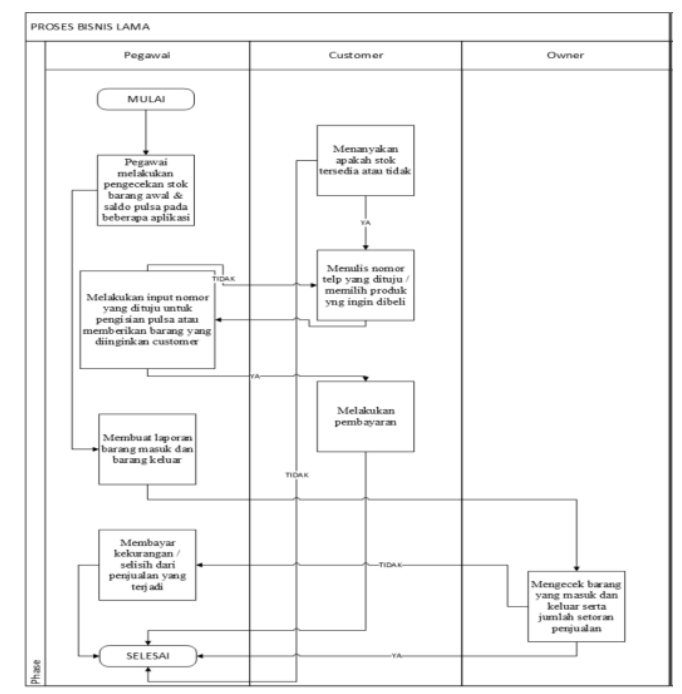

Gambar 2. Proses Bisnis Lama

\section{Analisis Proses Bisnis Baru}

Proses bisnis yang baru dibuat dengan memperbaharui sistem manual menjadi modern untuk mempermudah dalam proses data barang masuk dan barang keluar. Sistem informasi inventory point of sales adalah sistem yang dapat memberi informasi stok barang, data penjualan, data supplier, dan data pembelian barang, sistem ini juga berfungsi untuk memantau secara 
DOI: https://doi.org/10.33330/jurteksi.v6i2.407

Available online at http://jurnal.stmikroyal.ac.id/index.php/jurteksi

digital. Ditunjukkan pada Gambar 3.

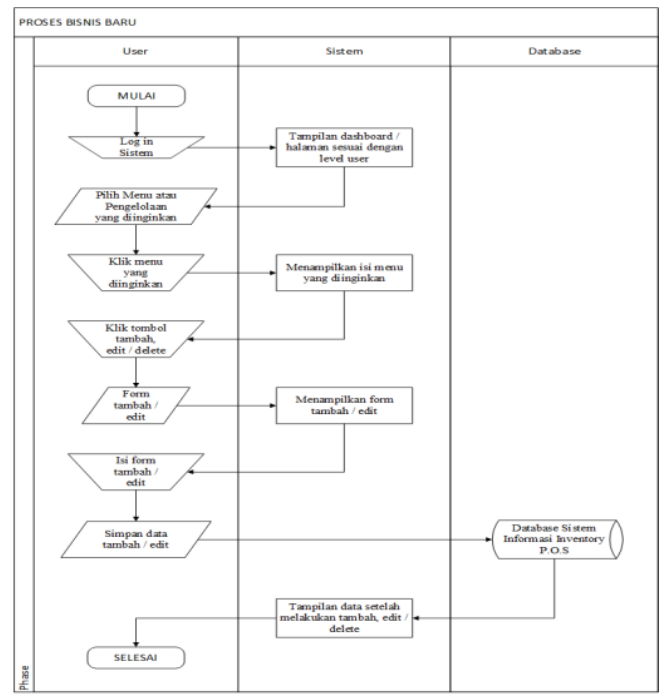

Gambar 3. Proses Bisnis Baru

\section{Perancangan Sistem}

Hasil perancangan sistem menggunakan UML didapatkan beberapa perancangan berupa:

\section{Diagram Konteks}

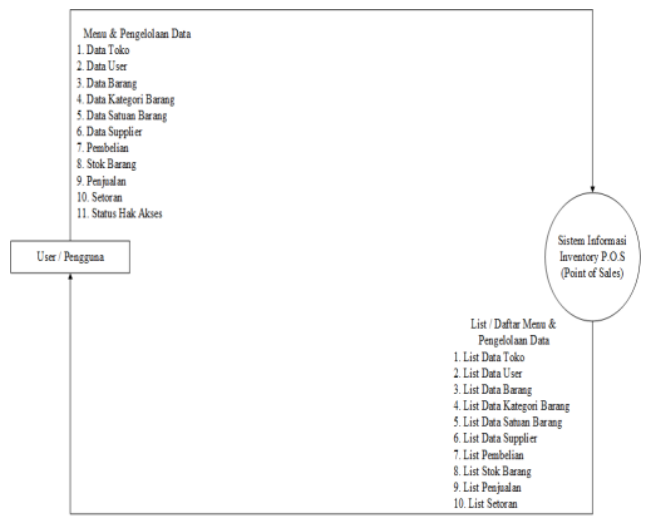

Gambar 4. Diagram Konteks

Diagram konteks merupakan diagram yang terdiri dari suatu proses dan menggambarkan ruang lingkup suatu sistem informasi penilaian kinerja tenaga pendidik yang dibangun [12]. Proses alur bisnis ini menjelaskan mengenai kegiatan pengguna (actor/user) terhadap sebuah sistem. Ditunjukkan pada Gambar 4.

\section{Diagram Use case}

Use case diagram merupakan sebuah grafik yang menggambarkan fungsi yang diharapkan dari sebuah sistem [11]. Use case diagram menjelaskan interaksi beberapa atau semua actor dalam suatu sistem agar mudah dipahami saat dilihat dari sudut pandangan orang luar. Ditunjukkan pada Gambar 5.

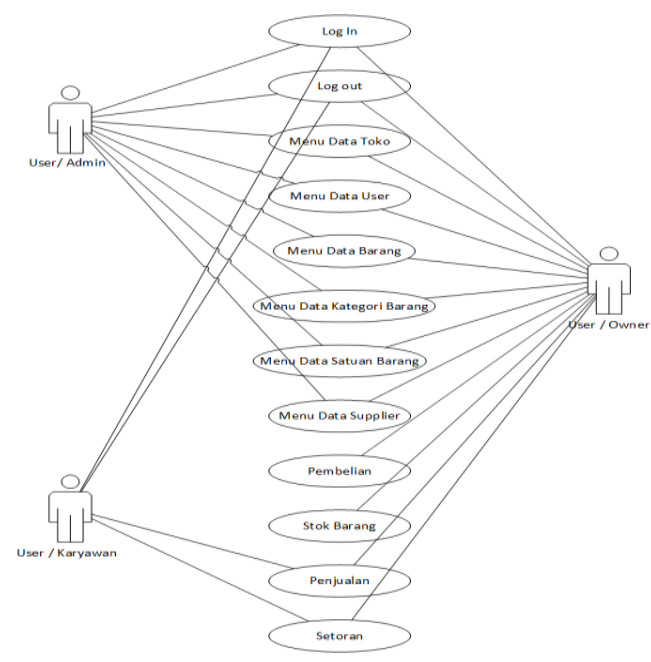

Gambar 5. Diagram Use case

\section{Activity Diagram}

Activity diagram merupakan diagram yang menggambarkan alur kerja dari berbagai macam kegiatan pengguna atau sistem [13]. Activity diagram ini menerangkan aktivitas yang dilakukan sebuah sistem dan bukan apa yang dilakukan oleh seorang actor/pengguna, jadi benarbenar aktivitas yang dilakukan sebuah sistem. Terdapat 12 activity diagram yang didapat dari penelitian ini, yaitu: Login, Logout, Menu Data Toko, Menu Data User, Menu Data Barang, 
DOI: https://doi.org/10.33330/jurteksi.v6i2.407

Available online at http://jurnal.stmikroyal.ac.id/index.php/jurteksi

Menu Data Kategori Barang, Menu Data Satuan Barang, Menu Data Suplier, Pengelolaan Pembelian, Pengelolaan Stok Barang, Pengelolaan Penjualan, Pengelolaan Setoran. Berikut salah satu activity diagram menu data barang ditunjukkan pada Gambar 6.

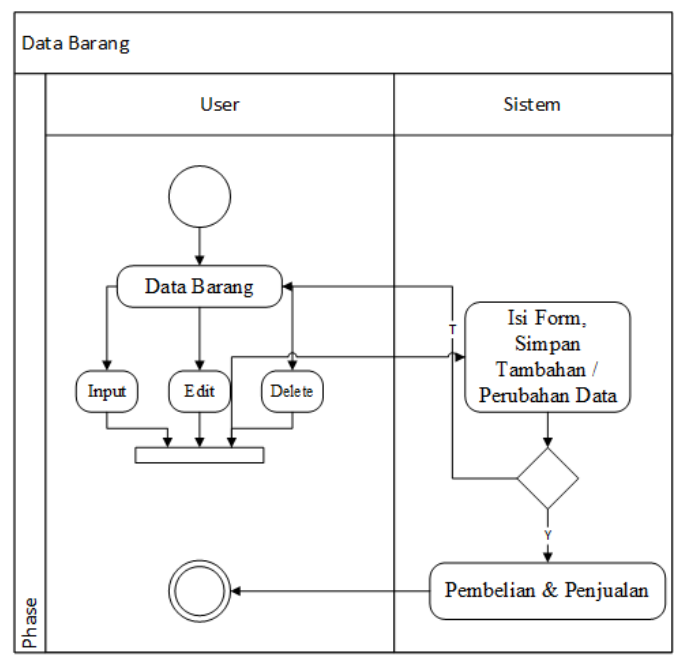

Gambar 6. Activity Diagram Menu Data Barang

\section{Class Diagram}

Class diagram merupakan model statis spesifikasi yang menggambarkan struktur atau deskripsi antar class dan terdiri dari nama kelas, attribut serta operasi/metode [13]. Class diagram yang didapat dalam penelitian ini dapat ditunjukkan pada Gambar 8 .

\section{Sequence Diagram}

Sequence diagram merupakan untuk menggambarkan skenario atau rangkaian langkah-langkah kolaborasi dinamis antara sejumlah objek yang dilakukan sebagai sebuah respon dari suatu kejadian untuk menghasilkan output tertentu [13]. Terdapat 13 squence diagram yang didapat dari penelitian ini, yaitu: Login, Logout, Dashboard Menu, Menu Data Toko, Menu Data User, Menu Data Barang, Menu Data Kategori Barang, Menu Data Satuan Barang, Menu Data Supplier, Pembelian, Stok Barang, Penjualan, Setoran.

\section{Component Diagram}

Component diagram merupakan diagram UML yang menampilkan komponen dalam sistem dan hubungan antar mereka [13]. Component diagram digunakan untuk memodelkan aspek fisik suatu sistem yang berupa modul-modul code seperti library maupun executable, file atau dokumen yang ada di dalam node. Component diagram yang didapat dalam penelitian ini dapat ditunjukkan pada Gambar 7.

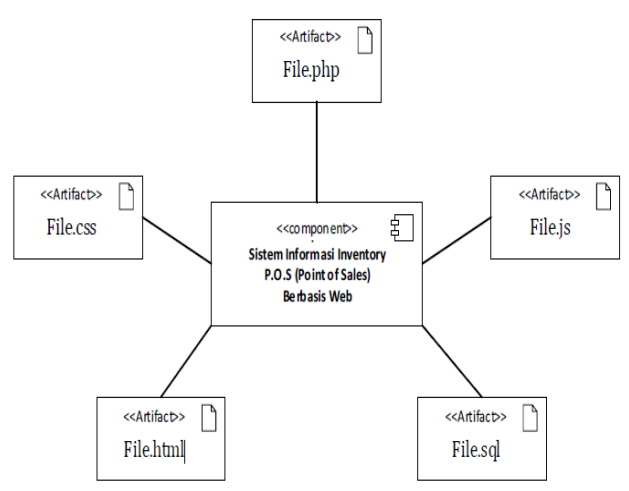

Gambar 7. Component Diagram

\section{Deployment Diagram}

Deployment diagram merupakan penggambaran $U M L$ yang mengerahkan artifact dalam node dan biasanya digunakan untuk memvisualisasikan, menspesifikasikan dan mendokumentasikan proses yang terjadi pada sebuah sistem perangkat lunak [13]. Sistem ini dijalankan pada web server dan database server. 
Vol. 6 No. 2, April 2020, hlm. 125 - 134

DOI: https://doi.org/10.33330/jurteksi.v6i2.407

Available online at http://jurnal.stmikroyal.ac.id/index.php/jurteksi

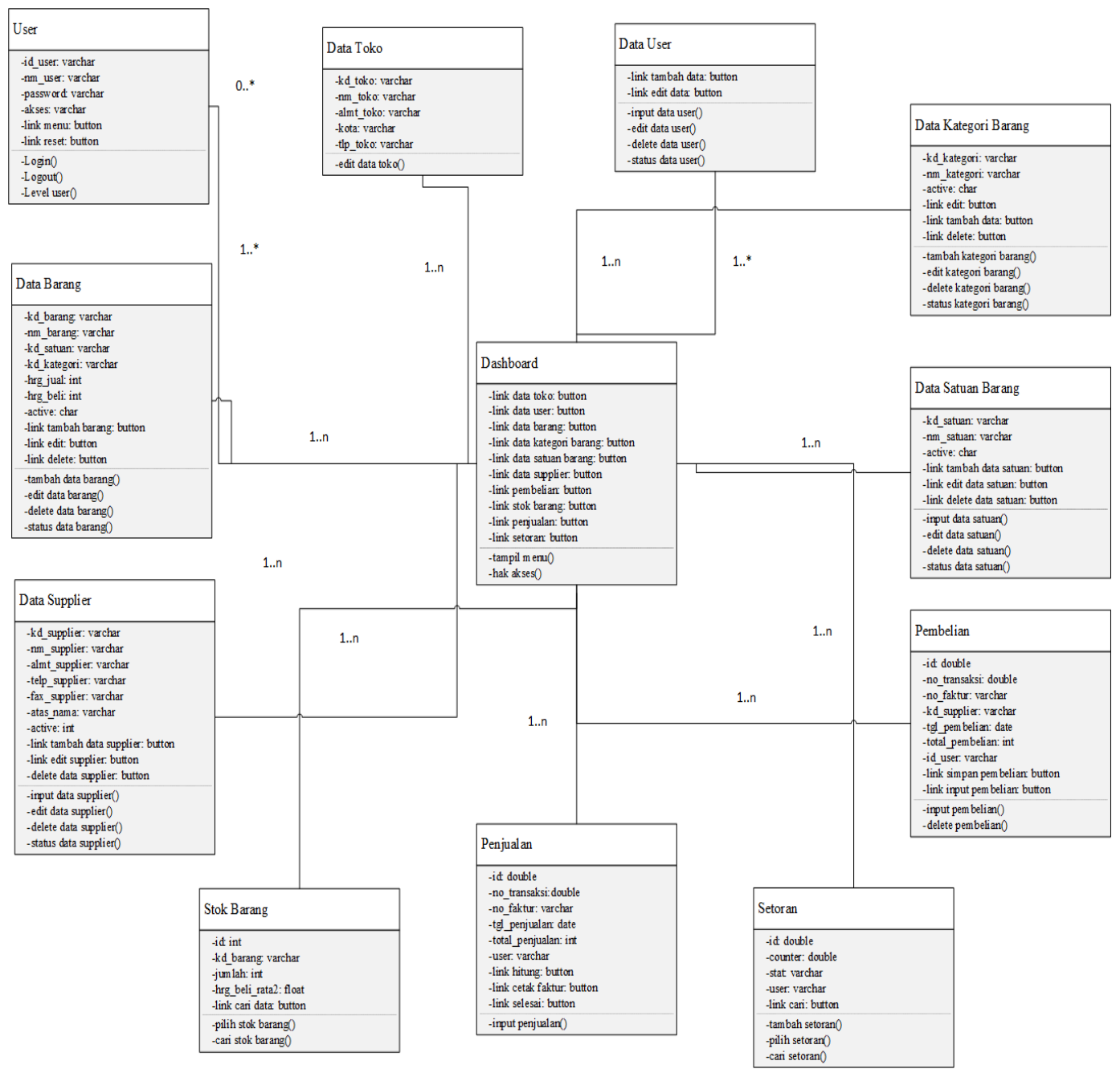

Gambar 8. Activity Diagram Menu Data Barang

Deployment diagram yang didapat dalam penelitian ini dapat ditunjukkan pada Gambar 9.

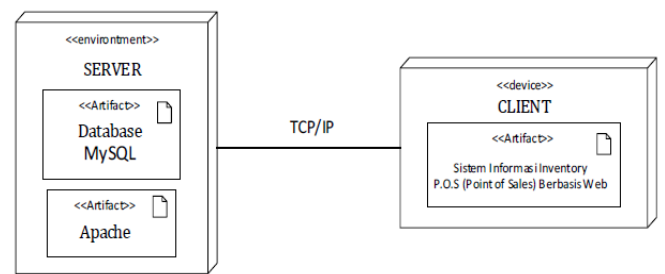

Gambar 9. Deployment Diagram

\section{Implementasi Sistem}

Halaman Dashboard

Pada halaman ini menampilkan daftar menu yang dapat digunakan ke dalam sistem. Halaman dashboard ditunjukkan pada Gambar 10.

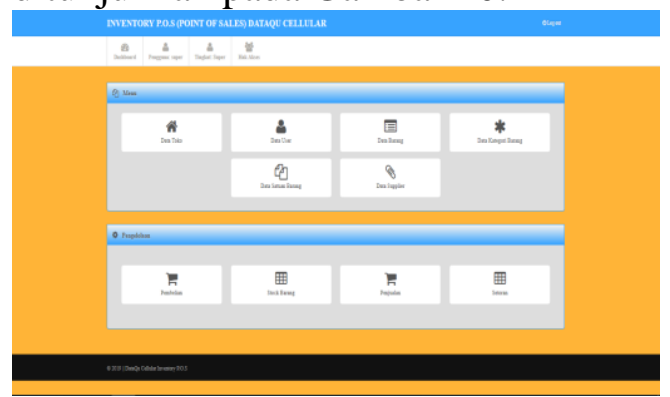

Gambar 10. Halaman Dashboard

Tampilan Data Toko

Pada halaman ini menampilkan data toko pada sistem. Halaman data toko 
JURTEKSI (Jurnal Teknologi dan Sistem Informasi)

Vol. 6 No. 2, April 2020, hlm. 125 - 134

DOI: https://doi.org/10.33330/jurteksi.v6i2.407

Available online at http://jurnal.stmikroyal.ac.id/index.php/jurteksi

ditunjukkan pada Gambar 11.

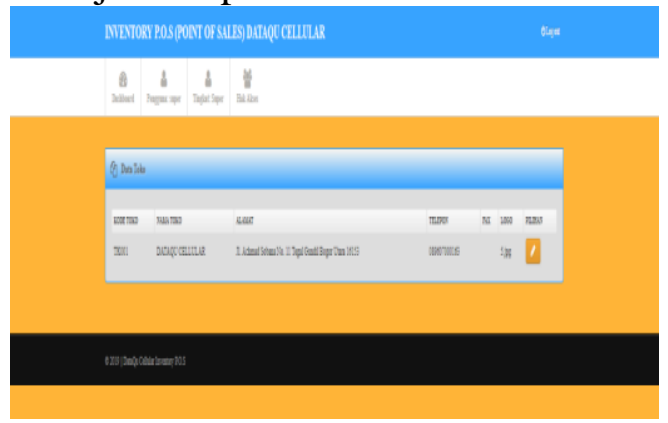

Gambar 11. Halaman Data Toko

Tampilan Data Supplier

Pada halaman ini menampilkan data supplier untuk mendata asal barang yang dibeli pada sistem. Halaman data supplier ditunjukkan pada Gambar 12.

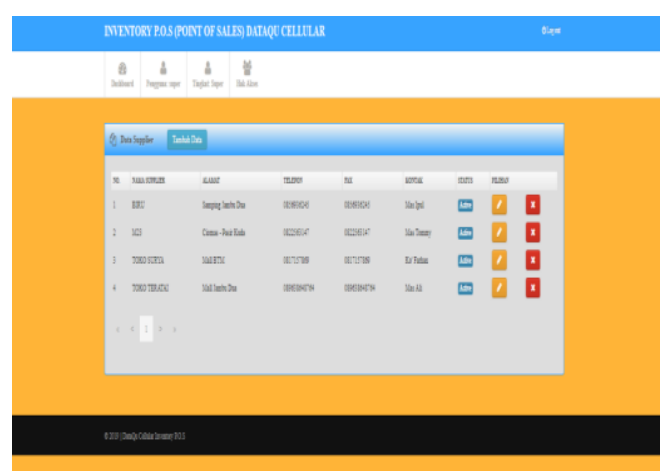

Gambar 12. Halaman Data Supplier

Tampilan Pembelian

Pada halaman ini menampilkan data sebagai bukti pembelian yang nantinya akan terhubung ke stok barang pada sistem. Halaman pembelian ditunjukkan pada Gambar 13.

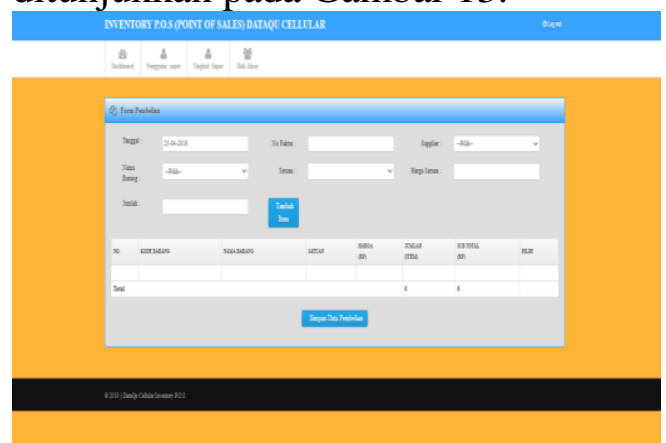

Gambar 13. Halaman Pembelian
Tampilan Penjualan

Pada halaman ini menampilkan data sebagai bukti barang keluar yang akan terhubung ke stok barang pada sistem. Halaman penjualan ditunjukkan pada Gambar 14.

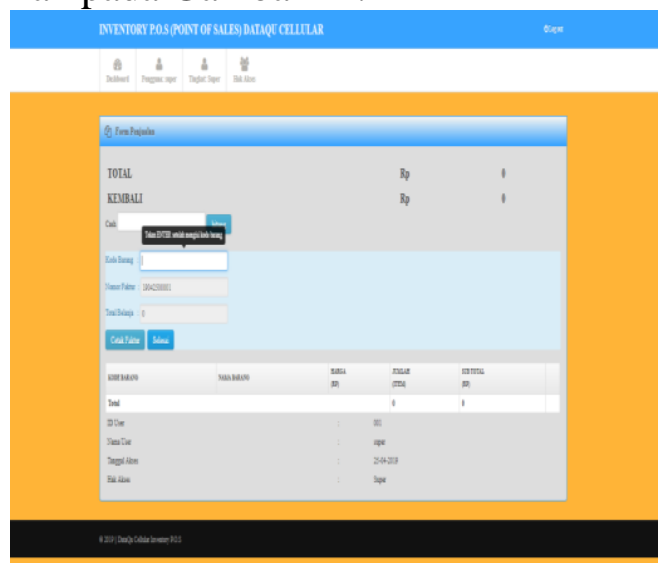

Gambar 14. Halaman Penjualan

\section{Pengujian Sistem}

Pengujian sistem dimaksudkan untuk menguji semua fungsi-fungsi pada perangkat lunak yang dibuat apakah sudah sesuai dengan yang diharapkan. Hal-hal yang akan diujikan menggunakan metode black box ini ditunjukkan pada Tabel 1 .

\section{Pengujian Sistem}

Pengujian sistem dimaksudkan untuk menguji semua fungsi-fungsi pada perangkat lunak yang dibuat apakah sudah sesuai dengan yang diharapkan. Hal-hal yang akan diujikan menggunakan metode black box ini ditunjukkan pada Tabel 1 .

Pengujian fungsional mencakup pengecekan tombol dan proses sistem apakah sudah berjalan sesuai dengan kebutuhan atau tidak. Hasil pengujian fungsional ditunjukkan pada Tabel 2. 
DOI: https://doi.org/10.33330/jurteksi.v6i2.407

Available online at http://jurnal.stmikroyal.ac.id/index.php/jurteksi

Tabel 1. Skenario Pengujian

\begin{tabular}{|c|c|c|}
\hline Kelas Pengujian & Butir Pengujian & Jenis Pengujian \\
\hline Login/ Data User/Logout & Login/Input-Edit-Delete/Logout & \multirow{10}{*}{ BlackBox } \\
\hline \multirow{9}{*}{ Menu } & Data Toko (Edit) & \\
\hline & Data Barang (Input-Edit-Delete) & \\
\hline & Data Kategori Barang (Input-Edit-Delete) & \\
\hline & Data Satuan Barang (Input-Edit-Delete) & \\
\hline & Data Supplier (Input-Edit-Delete) & \\
\hline & Pembelian (Input \& Delete) & \\
\hline & Penjualan (Input) & \\
\hline & Stok Barang (Pilih \& Cari) & \\
\hline & Setoran (Input, Pilih \& Cari) & \\
\hline
\end{tabular}

Tabel 2. Hasil Pengujian Black Box

\begin{tabular}{|c|c|c|c|}
\hline $\begin{array}{c}\text { Form } \\
\text { Pengujian }\end{array}$ & Skenario Pengujian & Hasil yang Diharapkan & $\begin{array}{c}\text { Hasil } \\
\text { Pengujian }\end{array}$ \\
\hline Login & $\begin{array}{l}\text { Klik Tombol Submit } \\
\text { dan Reset }\end{array}$ & $\begin{array}{l}\text { Dapat masuk ke dalam sistem } \\
\text { dengan akun yang telah dibuat }\end{array}$ & {$[\sqrt{]}$ Berhasil } \\
\hline $\begin{array}{l}\text { Input-Edit- } \\
\text { Delete User }\end{array}$ & $\begin{array}{l}\text { Klik Tombol Tambah- } \\
\text { Edit-Delete }\end{array}$ & $\begin{array}{l}\text { Dapat memanagement data user } \\
\text { sesuai keinginan owner }\end{array}$ & {$[\sqrt{ }]$ Berhasil } \\
\hline Logout & Klik Tombol Logout & $\begin{array}{l}\text { Keluar dari sistem agar tidak } \\
\text { disalahgunakan oleh pihak yang } \\
\text { tidak bertanggung jawab }\end{array}$ & {$[\sqrt{ }]$ Berhasil } \\
\hline \multirow{10}{*}{$\begin{array}{l}\text { Fungsi } \\
\text { Management } \\
\text { Menu }\end{array}$} & $\begin{array}{l}\text { Tampilan Halaman } / \\
\text { Dashboard Menu }\end{array}$ & $\begin{array}{l}\text { Dapat menampilkan menu sesuai } \\
\text { keinginan owner }\end{array}$ & {$[\sqrt{ }]$ Berhasil } \\
\hline & $\begin{array}{l}\text { Klik Menu Data Toko } \\
\text { (Tombol Edit) }\end{array}$ & $\begin{array}{lr}\text { Dapat mengakses } & \text { dan } \\
\text { memanagement } & \text { Deskripsi } \\
\text { keterangan toko } & \\
\end{array}$ & {$[\sqrt{]}$ Berhasil } \\
\hline & $\begin{array}{l}\text { Klik Menu Data Barang } \\
\text { (Tombol Tambah-Edit- } \\
\text { Delete) }\end{array}$ & $\begin{array}{l}\text { Untuk mengetahui jenis data barang } \\
\text { yang diperjual belikan }\end{array}$ & {$[\sqrt{]}$ Berhasil } \\
\hline & $\begin{array}{lr}\text { Klik Menu } & \text { Data } \\
\text { Kategori } & \text { Barang } \\
\text { (Tombol } & \text { Tambah-Edit- } \\
\text { Delete) } & \end{array}$ & $\begin{array}{l}\text { Dapat memanagement data untuk } \\
\text { dikelompokkan sesuai kategori } \\
\text { barang }\end{array}$ & {$[\sqrt{ }]$ Berhasil } \\
\hline & $\begin{array}{l}\text { Klik Menu Data Satuan } \\
\text { Barang (Tombol } \\
\text { Tambah-Edit-Delete) }\end{array}$ & $\begin{array}{l}\text { Dapat memanagement data untuk } \\
\text { dikelompokkan sesuai jenis satuan } \\
\text { barang }\end{array}$ & {$[\sqrt{ }]$ Berhasil } \\
\hline & $\begin{array}{l}\text { Klik Menu } \begin{array}{r}\text { Data } \\
\text { Supplier } \\
\text { Tambah-Edit-Delete) }\end{array} \\
\end{array}$ & $\begin{array}{l}\text { Untuk kelola identitas data Supplier, } \\
\text { sumber barang masuk }\end{array}$ & {$[\sqrt{ }]$ Berhasil } \\
\hline & $\begin{array}{l}\text { Klik Menu Pembelian } \\
\text { (Tombol Tambah \& } \\
\text { Delete) }\end{array}$ & $\begin{array}{l}\text { Sebagai bukti untuk laporan adanya } \\
\text { proses pembelian pada supplier } \\
\text { (barang masuk) }\end{array}$ & {$[\sqrt{ }]$ Berhasil } \\
\hline & $\begin{array}{l}\text { Klik Menu Penjualan } \\
\text { (Tombol Tambah) }\end{array}$ & $\begin{array}{l}\text { Sebagai bukti untuk laporan adanya } \\
\text { proses penjualan pada customer } \\
\text { (barang keluar) }\end{array}$ & {$[\sqrt{ }]$ Berhasil } \\
\hline & $\begin{array}{l}\text { Klik Menu Stok Barang } \\
\text { (Tombol Pilih \& Cari) }\end{array}$ & $\begin{array}{l}\text { Untuk mengelola data barang yang } \\
\text { keluar dan masuk }\end{array}$ & {$[\sqrt{]}$ Berhasil } \\
\hline & $\begin{array}{l}\text { Klik Menu Setoran } \\
\text { (Tombol Tambah-Pilih- } \\
\text { Cari) }\end{array}$ & $\begin{array}{l}\text { Untuk bukti laporan penjualan } \\
\text { dengan jumlah uang yang sebanding }\end{array}$ & {$[\sqrt{ }]$ Berhasil } \\
\hline
\end{tabular}


JURTEKSI (Jurnal Teknologi dan Sistem Informasi)

Vol. 6 No. 2, April 2020, hlm. 125 - 134

DOI: https://doi.org/10.33330/jurteksi.v6i2.407

Available online at http://jurnal.stmikroyal.ac.id/index.php/jurteksi

\section{SIMPULAN}

Simpulan dari penelitian ini adalah: Proses perancangan dan pembangunan Sistem Informasi Inventory P.O.S (Point of Sales) di COUNTER DATAQU CELLULAR telah berhasil dengan hasil rancangan yang telah di buat berupa diagram konteks, perancangan database, dan UML diagram (Use Case Diagram, Activity Diagram, Class Diagram, dan Sequence Diagram). Hasil pengujian aplikasi menggunakan metode black box yang dilakukan terhadap kinerja Sistem Informasi Inventory P.O.S (Point of Sales) telah beroperasi dengan baik dan sesuai dengan keinginan owner.

\section{UCAPAN TERIMA KASIH}

Terima kasih kepada Pimpinan dan COUNTER DATAQU CELLULAR yang telah banyak memberikan dukungan dalam penelitian ini.

\section{DAFTAR PUSTAKA}

[1] R. Seto, "Hasil Survei: Masyarakat Lebih Pilih Pulsa Dibanding Daging," Majalah Infovet I Majalah Peternakan dan Kesehatan Hewan., 2018. .

[2] P. Dika, A. Wiguna, I. P. Agus, I. P. Satwika, and S. Artikel, "Rancang Bangun Aplikasi Point of Sales Distro Management System dengan Menggunakan Framework React Native," J. Nas. Teknol. dan Sist. Inf., vol. 04, no. 03, pp. 149-159, 2018.

[3] K. Mukherjee, "Technology at
Point-of-Purchase-A Journey from Electronic Cash Registers to all Inclusive Point-ofPurchase Systems," Asian J. Appl. Sci. Technol., vol. 1, no. 8, pp. 1-4, 2017.

[4] W. Damayanti, J. Jemakmum, and S. Suyanto, "Rancang Bangun Aplikasi Point Of Sales Pada Apotek Kamila Berbasis Web," in Bina Darma Conference on Computer Science, pp. 244-252.

[5] H. Agusvianto, "Sistem Informasi Inventori Gudang Untuk Mengontrol Persediaan Barang Pada Gudang Studi Kasus : PT.Alaisys Sidoarjo Hendra," J. Inf. Eng. Educ. Technol., vol. 01, no. 01, pp. 40-46, 2017.

[6] D. Anggraeni, "Sistem informasi pengelolaan daerah aliran sungai di bpdas kota padang," JURETKSI, vol. 4, no. 1, pp. 29-36, 2017.

[7] W. Nurdina, S. R. Andani, P. Poningsih, and S. Solikhun, "Nurdina, W., Andani, S. R., Poningsih, P., \& Solikhun, S. (2020, February). Perancangan Sistem Informasi Pelayanan Masyarakat Pada Kantor Camat Tapian Dolok," in Seminar Nasional Teknologi Komputer \& Sains (SAINTEKS), 2020, pp. 224-227.

[8] M. I. Nurhayati, N., \& Syarif, "SISTEM INFORMASI PENGHITUNG STOK BARANG MENGGUNAKAN METODE FIRST INPUT FIRST OUTPUT (FIFO) dan ECONOMIC ORDER QUANTITY (EOQ),,$\quad J$. 
DOI: https://doi.org/10.33330/jurteksi.v6i2.407

Available online at http://jurnal.stmikroyal.ac.id/index.php/jurteksi

Teknol. Elekterika, vol. 14, no. 1, pp. 16-25, 2017.

[9] E. P. Prasetyo, "MEDIA INFORMASI BERBASIS WEB PADA SMA ISLAM ALAMALUL KHAIR PALEMBANG," $J . \quad T I P S \quad J$. Teknol. Inf. dan Komput. Politek. Sekayu, vol. 9, no. 2, pp. 10-19, 2019.

[10] T. G. Yuarita, F. Marisa, J. T. Informatika, and U. W. Malang, "PERANCANGAN APLIKASI POINT OF SALES ( POS ) BERBASIS WEB MENGGUNAKAN METODE SIKLUS HIDUP," J. Teknol. dan Manajement Inform., vol. 3, no. 2, pp. 167-171, 2017.

[11] G. T. Negara and A. S. Pardiansyah, "RANCANG
BANGUN $\quad$ SISTEM

MESSAGE SERVICE (SMS)

GATEWAY UNTUK

INFORMASI KEGIATAN

PERSERTA CALON

ANGGOTA POLRI," $J$.

Teknol. dan Sist. Inf., vol. IV, no. 2, pp. 9-14, 2018.

[12] Y. Afrianto et al., "Rancang bangun sistem informasi penilaian kinerja tenaga pendidik di fakultas teknik dan sains universitas ibn khaldun," J. Mantik Penusa, vol. 3, no. 1, pp. 151-160, 2019.

[13] B. Satzinger, Jackson, System Analysis and Design with the Unified Process. USA: Course Technology, 2010. 